thirty-eight inches in circumference, the apex of the heart beating in the second space, and the distension caused him the greatest distress. A drainage-tube was left in, through which a considerable quantity of urine drained daily into a vessel arranged for the purpose. The abundant discharge of arine through the fistulous opening was the factor that determined the parents in desiring the removal of the tumour, and the operation was therefore performed on Feb. $27 \mathrm{tb}$, 1897. On exposing the outer aspect of the tumour by means of an incision in the left side, and on laying it open, the band entered a cavity of such considerable size that it was felt to be undesirable to incur what wou'd have been a very considerable risk by its removal, especially as the wound might possibly not be asseptic. I therefore examined the exposed portion of the tumour to discover how far the mass was made up of distended pelvis and ureter, and how much of dilated kidney substance. This I arrived at by stripping off the capsule from what was obviously reval tissue, when it was fonnd that about a tenth only of the wall of the cyst was formed of kidney substance, the remainder being apparently made up of the pelvis and ureter enormously dilated. The sidney was carefully cut away along its limits, which were readily indicated by the reflection of its capsule, each portion being firmly ligatured previonsly to being cut through. The ligatures were left long so as to serve as a drain from the cemainder of the cyst-wall left. At no time after the operation did any discharge of urine take place from the wound, which was kept open only by the ligatures, which came away after varying intervals of time.

St. Thomas's-street, S.E.

\section{AN ANTISEPTIC ALKALINE TABLOID FOR NASO-PHARYNGEAL DISEASES.}

By Herbert Tillex, M.D., B.S.LosD., \&c., ASISTAYT SURGEON TO THE LONDON EAR AND THROAT HOSPITAL.

HAVING had more than twelve months' experience with the fabloid about to be described, I can confidently recommend it to the profession for use in those cases of naso-pharyngeal diseases where an alkaline antiseptic wash is advisablesuch cases, for exsmple, as ozæna, chronic nasal catarrh, and purulent discharges from the accessory nasal cavities after removal of polypi, \&c. The obvious difficulty was to combine the carbolic acid and sodium bicarbonate; but after much trouble Messrs. Burroughs and Wellcome succeeded in doing so, and the convenience of the tabloid to patients suffering from diseases similar to those described is inestimable. There is nothing new in the combination of drugs employed, as is seen at once in its composition-viz., twelve graius of bicarbonate of sodium, a grain and a halt of carbolic acid, and two grains of chloride of sodium. I purposely excluded borax, because I shared the experience of some other rhinologists that many patients complain of a sense of dryness in their nose when using lotions containing borax, which disappeared when the latter drug was eliminated from the lotion. The second and most obrious adrantage is that of expense to the patient. Many have to continue using lotions for a long while, and the necessity of having a fresh supply every fifth or sixth day often results in patients giving up a treatment which would much benefit them if continued. The tabloids are very soluble in water, and, indeed, are so hygroscopic that they should be kept well corked. One tabloid dissolved in about two ou aces of lukewarm water gives a solution of sufficient strength for ordinary cases, but the suitable strength can soon be best gauged by the patient himself. A bottle containing 100 tabloids is sold for about $2 s$. and in an ordinary way wonld last about two months. Such a combination of drugs is so commonly ordered in naso-pharyngeal cases that its conFenience in this form is my reason for bringing it to notice.

College-crescent, South Hamivstead, N.W.

BLACKPOOL HosPITAL.-The trustees of this hospital have received through Dr. Kingsbury, the consulting physician, the following donations :-Anonymous (to build two additional wards), $\$ 1000 ; \mathrm{Mr}$. James Parrott (to endow one bed in rerpetuity), $£ 1000$; Miss Haworth, $£ 250$; Mr. James Higgin, £100.

\section{Athirrox}

\section{H O S P I T A L P R A C T I C E, BRITISH AND FOREIGN.}

Nulla autem est alia pro certo noscendi via, nisi quamplurimas et mor borum et dissectionum historias, tum aliorum tum proprias collectas habere, et inter se comparare.-MORGAGNI De Sed. et Caus. Morb. lib. iv. Procmium.

\section{ST. THOMAS'S HOSPITAL.}

A SERTES OF CASES ILLUSTRATING THE SUCCESS ATTENDING THE MODERN METHOD OF OPERATION FOR STRANGULATHD HERNIA.

(Concluded from p. S53.)

(Cases under the care of Mr. W. H. BAtTLE.)

THESE four cases of operation for strangulated hernia are a continuation of the series of which we published seven in the last issue of The LANCET. We consider that they form a very good illustration of the success of the modern method of herniotomy, as they are not selected cases, but represent all hernix which required operation during a period of ten days at one hospital. There is nothing unusual in the methods employed; probably the same cases would have been treated with equal success at any of our large hospitals. None of them presented the more serious conditions which militate against successful operation; there were no cases of gangrene, or ulceration of gut, or of adbesion of intestine to the sac. In all, with one exception, the condition permitted of the performance of a radical cure after reduction of the hernia. In order that a patient may have the best chance afforded by the modern operation, it is necessary that operation should be performed early and that attempts at taxis have not been too severe or too prolonged. This fact is emphasised by the recently published paper by Mr. John Croft, the majority of whose cases were drawn from the district trom which these came. Of forty-four operations for strangulated hernia performed by him with antiseptic precautions nine died exhausted as a result of their protracted sufferings, while five were already moriband when admitted. We hope the series now published may be taken as an indication that recognition of the importance of early operative relief on the failure of moderate taxis is better appreciated thar it was amongst those who see the patients first. At all events, we would impress on the profession the fact that the mortality from strangulated hernia has no right to be so high as 35.8 per cent., as was recently estimated to be the average at a large hospital. When our students are fully impressed with the importance and aafety of early operation it will not be long before the public recognises it. So many operations have been performed in the past on patients who have died soon afterwards that there is still trouble to make friends understand that it is not the operation that kills but its performance on an exhausted patient. The immensely important points in these cases are evident on reading the account. We would, however, draw attention to the rarity of interstitial hernia (forming 0.13 per cent. of all cases of inguinal hernia in the male), of which Case 8 is a good example of the more usual of the three varieties into which they are divided; and to the effect of tazis in Case 9 , the local effect of ice on the contents of the sac. and to the temporary albuminuria of unexplained origin. In Case 10 the patient was a stout man, who complained of no cough or illness before admission, but was probably alcoholic. How far the ether may have acted in arousing a latent tuberculous focus it is not possible to say. Without actual examination of the sac and its contents it was hardly possible to tell for certain that the hernia was a direct one. The great similarity of the two hernix, their shape, and the fact that they did not enter the scrotum, together with their short duration, made it probable. The gut was evidently sharply nipped in Case 11, for the patient suffered much more pain than usual, and after the relief of strangulation there was a complaint of abdominal pain ard discomfort, only relieved by the passage of the long tube and 